\title{
Aspirin and colorectal cancer chemoprevention
}

\author{
Gurpreet Singh-Ranger ${ }^{1,2}$ \\ 'Department of Surgery, Upper River Valley Hospital, New Brunswick E7P OA4, Canada. \\ ${ }^{2}$ Department of Biology, Faculty of Science, Mount Allison University, Sackville, New Brunswick E4L 1E2, Canada.
}

Correspondence to: Prof. Gurpreet Singh-Ranger, Department of Surgery, Upper River Valley Hospital, 11300 Route 130, Waterville, New Brunswick E7P 0A4, Canada.E-mail: gsinghranger@yahoo.co.uk

How to cite this article: Singh-Ranger G. Aspirin and colorectal cancer chemoprevention. Mini-invasive Surg 2018;2:39. http://dx.doi.org/10.20517/2574-1225.2018.23

Received: 9 May 2018 First Decision: 8 Oct 2018 Revised: 5 Nov 2018 Accepted: 5 Nov 2018 Published: 21 Nov 2018

Science Editor: Gordon N. Buchanan Copy Editor: Huan-Liang Wu Production Editor: Cai-Hong Wang

\begin{abstract}
The role of aspirin in colorectal cancer prevention is currently under intense scrutiny. Low dose Aspirin effectively suppresses the cyclooxygenase-2 enzyme system, which is thought to play an important role in the pathogenesis of colorectal cancer. A number of observational studies and randomized controlled trials have supported a chemoprevention effect. In some instances, regular use of low dose aspirin has provided a nearly $20 \%$ reduction in incidence. Compliance and underutilization remain important issues however, as does the incidence of side effects - aspirin is a non-steroidal anti-inflammatory drug, and regular use of these medications carries a small but significant risk of gastrointestinal bleeding, which on occasion, can be life-threatening. These are important problems, which need wider recognition and detailed exploration before we can suggest widespread use of aspirin in primary or secondary prevention.
\end{abstract}

Keywords: Colorectal cancer, adenomas, aspirin, non-steroidal anti-inflammatory drugs, chemoprevention, cyclooxygenase-2

\section{INTRODUCTION}

The incidence of rectal cancer has increased over the last decade ${ }^{[1]}$. Left undiagnosed, patients can present with untreatable or stage IV disease, and even when recognised relatively early, cases are often locally advanced, and require a combination of major surgery, chemotherapy and radiotherapy to attempt cure.

With the advent of laparoscopic, and now robotic resection, the rectal cancer patient is relieved of some of the discomforts of treatment, but one of the most desired intentions of rectal cancer treatment would be to prevent or treat the disease at an earlier stage. Most left-sided cancers develop from an earlier adenoma 
Table 1. Observational studies with aspirin and colorectal cancer chemoprevention

\begin{tabular}{|c|c|c|c|c|}
\hline Study & Design & Aspirin use & Duration & Relative risk \\
\hline Nurses Health Study ${ }^{[8]}$ & Cohort & More than 2x per week & 10 & 0.62 \\
\hline Cancer Prevention Study ${ }^{[9]}$ & Cohort & Various & 15 & $0.58-0.61$ \\
\hline Health Professionals Study ${ }^{[10]}$ & Cohort & More than $2 x$ per week & 4 & 0.54 \\
\hline
\end{tabular}

phase. We now know that unregulated prostaglandin expression appears to have some importance in the early phase of adenoma formation, and transition to invasive cancer $^{[2,3]}$.

\section{COLORECTAL CANCER CHEMOPREVENTION}

The cyclooxygenase (COX) enzymes act on arachidonic acid to permit formation of prostaglandins. There are two isoenzymes; Generally speaking, although this is slightly simplistic, COX-1 is responsible for stable expression of "useful" prostaglandins in cells ${ }^{[3,4]}$, whilst COX-2 expression occurs by stimulation in various pathological environments, and typically by those factors which are present in malignant disease and chronic inflammation ${ }^{[5,6]}$. Once induced, COX-2 can create a situation of uncontrolled prostaglandin release, which thereby promotes the genesis and growth of malignant cells in various ways ${ }^{[7]}$. A cell which is initially only mildly dysplastic, can, in the environment of persistent prostaglandin release, transform into more severe dysplasia and frankly, cancer.

The adenoma-cancer transformation occurs over many years in most patients, although there are exceptions. The lag period provides a potential pathway for a suitable intervention to reduce cancer risk - typically, we have thought about polyp removal in this regard, the purpose of colon cancer screening program, now prevalent in most countries. What if however, we could terminate the transition of the cell on the brink of turning dysplastic or malignant in some way, with drugs that inhibit prostaglandin synthesis?

Low dose aspirin, already taken worldwide to in the secondary prevention of ischaemic heart disease, blocks COX and prostaglandin formation, so would seem to be a prime candidate. Indeed, studies as far back as 20 years ago suggested some usefulness in this regard ${ }^{[8-10]}[$ Table 1$]$. The results of formal randomised controlled trials (RCTs) in the 1990s and early 2000s were disappointing however, and did not substantiate results from previous observational studies ${ }^{[1,12]}$.

Towards the end of the last decade however, the longer term results of the aforementioned RCTs and other more recent trials suggested a significant reduction in colorectal cancer incidence after 10 years of use ${ }^{[13,14]}$ [Table 2].

Patients probably need to take aspirin or related drugs regularly for about 3 years before realising an anticancer benefit, and even if they then stop using the medication, there still may exist some long term protective effect lasting up to 10 years or more, which indicates we might be able to suggest patients take aspirin for a defined period, and then be less strict about compliance and adherence after that time, particularly if there is an issue with adverse effects.

Furthermore, another positive insight from trials is that maintaining patients on a low dose for example, $75-81 \mathrm{mg}$, is sufficient to allow risk reduction in those with a polyp history ${ }^{[15,16]}$ - this was actually previously also suggested by observational work ${ }^{[17]}$.

An anticancer action for aspirin at low dose seems paradoxical however - extraordinarily high doses of aspirin (over $1 \mathrm{~g} /$ day) are required to terminate COX-2 expression in nucleated cells ${ }^{[18]}$. Recent studies suggest the low dose strategy works due to inactivation of platelet COX-1 - a strong induction signal for COX-2 upregulation in damaged cells ${ }^{[19]}$. Recent work also indicates there may be other isolated mechanisms 
Table 2. Long term follow-up data from randomised controlled trials

\begin{tabular}{|c|c|c|c|c|c|c|}
\hline Study & Design & $\begin{array}{c}\text { Duration } \\
\text { (years) }\end{array}$ & Number of patients & $\begin{array}{l}\text { Colon cancer } \\
\text { hazard ratio }\end{array}$ & $P$ value & $\begin{array}{l}\text { GI bleed/ } \\
\text { peptic ulcer }\end{array}$ \\
\hline Cook NR ${ }^{[13]}$ & $\begin{array}{l}\text { Post RCT observational } \\
\text { follow-up }\end{array}$ & 10 & $\begin{array}{l}33,682 \\
\text { ( } 84.5 \% \text { of original } \\
\text { participants) }\end{array}$ & $\begin{array}{l}0.80 \text { overall } \\
\text { ( } 0.73 \text { proximal } \\
\text { tumors) }\end{array}$ & $\begin{array}{c}0.021 \\
(0.022)\end{array}$ & \\
\hline Rothwell $P M^{[14]}$ & $\begin{array}{l}\text { Post RCT data follow up } \\
\text { ( } 5 \text { trials) }\end{array}$ & 20 & 17,164 & $\begin{array}{l}0.58 \text { rectal } \\
\text { (0.35 proximal } \\
\text { tumors) }\end{array}$ & $<0.01$ & Not reported \\
\hline
\end{tabular}

of effect to prevent cancer - the phosphatidylinositol 3-kinase-related pathway ${ }^{[20]}$, "induced-senescence" by interference of the sirtuin1 metabolic pathway ${ }^{[21]}$, and clotting factor acetylation ${ }^{[22]}$.

The aforementioned provides strong support for the case for using aspirin to prevent rectal cancer, but there are serious potential problems that need consideration.

Firstly, there is the small but dose-dependent risk of haemorrhagic stroke and gastrointestinal bleeding ${ }^{[23]}$. This might be deemed relatively acceptable in patients already on aspirin for ischaemic heart disease, but could be a serious issue in younger and otherwise healthy patients being asked to take the medication for chemoprevention long term - and has been noted as a risk in randomised controlled trials [Table 2].

Secondly, there are known to be cases where aspirin does not "work", even when taken regularly. This phenomenon of persistent platelet activation has long been recognised as a cause of persistent strokes/angina or myocardial infarction in around one quarter of compliant patients taking therapeutic dose aspirin ${ }^{[24,25]}$.

The reasons for "aspirin resistance" are variable, probably involving supranormal rates of platelet turnover in some patients, suboptimal levels of actual agent entering the circulation, and possibly different pathways for thromboxane A2 synthesis and abnormal variants of $\mathrm{COX}^{[26]}$. Aspirin bioavailability can vary from $20 \%$ $40 \%$ and differs markedly depending on route of administration, and formulation - for example, soluble aspirin has better bioavailability than tablet form ${ }^{[27,28]}$, and some co-administered agents and lifestyle factors can have profound effects on bioavailability ${ }^{[29,30]}$.

Tolerance occurs over time, and is not completely responsive to increased dosing ${ }^{[31]}$. Studies of aspirin use in cardiovascular disease indicate compliance and non-adherence are significant problems - associated with age, co-morbidity and polypharmacy - essentially in groups who would probably benefit from aspirin $\operatorname{most}^{[32]}$. Our own preliminary work suggests that although side effect reporting is low $(<6 \%)$, only a quarter of patients are fully compliant with treatment ${ }^{[33]}$, and underuse may be associated with female gender, the presence of comorbidities and polypharmacy.

\section{CONCLUSION}

In summary, regular low dose aspirin would seem to be an ideal candidate for low risk prevention of rectal cancer based on the most recent research, however, concerns about side effects, underutilisation and compliance may indicate a selective role only. In the prevention of ischaemic heart disease, aspirin use is restricted to specific subgroups, and not recommended for general use in primary prevention due to the incidence of the aforementioned side effects in otherwise healthy patients. One potential target group could be those at higher risk of a heart attack or stroke, and who do not have risk factors for stomach bleeding, with the aim of preventing both cardiovascular disease and colorectal cancer. Concerns regarding adverse effects might also limit use of aspirin in those groups at particular risk of colorectal cancer, such as patients with hereditary polyposis or Lynch syndrome, and more work is required to clarify the risk - benefit ratio in these high risk groups. 


\section{DECLARATIONS}

\section{Authors' contributions}

Singh-Ranger G conceived and wrote the article.

\section{Availability of data and materials}

Not applicable.

\section{Financial support and sponsorship}

None.

\section{Conflicts of interest}

There are no conflict of interests.

\section{Ethical approval and consent to participate}

Not applicable.

\section{Consent for publication}

Not applicable.

\section{Copyright}

(c) The Author(s) 2018.

\section{REFERENCES}

1. Jemal A, Center MM, DeSantis C, Ward EM. Global patterns of cancer incidence and mortality rates and trends. Cancer Epidemiol Biomarkers Prev 2010;19:1893-907.

2. Pugh S, Thomas GA. Patients with adenomatous polyps and carcinomas have increased colonic mucosal prostaglandin E2. Gut 1994;355:675-8.

3. Giardiello FM, Casero RA Jr, Hamilton SR, Hylind LM, Trimbath JD, et al. Prostanoids, ornithine decarboxylase, and polyamines in primary chemoprevention of familial adenomatous polyposis. Gastroenterology 2004;1262:425-31.

4. Singh Ranger G. Current Concepts in colorectal cancer prevention with cyclooxygenase inhibitors. Anticancer Res 2014;34:6277-82.

5. Herschman HR. Prostaglandin synthase-2. Biochim Biophys Acta 1996;1299:125-40.

6. Adegboyega PA, Ololade O. Immunohistochemical expression of cyclooxygenase-2 in normal kidneys. Appl Immunohistochem Mol Morphol 2004;12:71-4.

7. Ranger GS, Thomas V, Jewell A, Mokbel K. Elevated cyclooxygenase-2 expression correlates with distant metastases in breast cancer. Anticancer Res 2004;24:2349-51.

8. Chan AT, Giovannucci EL, Meyerhardt JA, Schernhammer ES, Curhan GC, et al. Long-term use of aspirin and nonsteroidal antiinflammatory drugs and risk of colorectal cancer. JAMA 2005;294:914-23.

9. Thun MJ, Namboodiri MM, Heath CW Jr. Aspirin use and reduced risk of fatal colon cancer. N Eng1 J Med 1991;325:1593-6.

10. Giovannucci E, Rimm EB, Stampfer MJ, Colditz GA, Ascherio A, et al. Aspirin use and the risk for colorectal cancer and adenoma in male health professionals. Ann Intern Med 1994;121:241-6.

11. Gann PH, Manson JE, Glynn RJ, Buring JE, Hennekens CH. Low-dose aspirin and incidence of colorectal tumors in a randomized trial. J Natl Cancer Inst 1993;85:1220-4.

12. Cook NR, Lee IM, Gaziano JM, Gordon D, Ridker PM, et al. Low-dose aspirin in the primary prevention of cancer: the Women's Health Study: a randomized controlled trial. JAMA 2005;294:47-55.

13. Cook NR, Lee IM, Zhang SM, Moorthy MV, Buring JE. Alternate-day, low-dose aspirin and cancer risk: long-term observational follow-up of a randomized trial. Ann Intern Med 2013;159:77-85.

14. Rothwell PM, Wilson M, Elwin CE, Norrving B, Algra A, et al. Long-term effect of aspirin on colorectal cancer incidence and mortality: 20-year follow-up of five randomised trials. Lancet 2010;376:1741-50.

15. Baron JA, Cole BF, Sandler RS, Haile RW, Ahnen D, et al. A randomized trial of aspirin to prevent colorectal adenomas. N Engl J Med 2003;348:891-9.

16. Cuzick J, Thorat MA, Bosetti C, Brown PH, Burn J, et al. Estimates of benefits and harms of prophylactic use of aspirin in the general population. Ann Oncol 2015;26:47-57.

17. Breuer-Katschinski B, Nemes K, Rump B, Leiendecker B, Marr A, et al. Long-term use of nonsteroidal antiinflammatory drugs and the risk of colorectal adenomas. The Colorectal Adenoma Study Group. Digestion 2000;61:129-34.

18. Patrono C, Coller B, FitzGerald GA, Hirsh J, Roth G. Platelet-active drugs: the relationships among dose, effectiveness, and side 
effects: the Seventh ACCP Conference on Antithrombotic and Thrombolytic Therapy. Chest 2004;126:234S-64S.

19. Patrono C, Patrignani P, Garcia Rodriguez LA. Cyclooxygenase-selective inhibition of prostanoid formation: transducing biochemical selectivity into clinical read-outs. J Clin Invest 2001;108:7-13.

20. Liao X, Lochhead P, Nishihara R, Morikawa T, Kuchiba A, et al. Aspirin use, tumor PIK3CA mutation, and colorectal-cancer survival. N Engl J Med 2012;367:1596-606.

21. Langley RE, Rothwell PM. Potential biomarker for aspirin use in colorectal cancer therapy. Nat Rev Clin Oncol 2013;10:8-10.

22. Jung YR, Kim EJ, Choi HJ, Park JJ, Kim HS, et al. Aspirin targets SIRT1 and AMPK to induce senescence of colorectal carcinoma cells. Mol Pharmacol 2015;88:708-19.

23. Serebruany VL, Malinin AI, Eisert RM, Sane DC. Risk of bleeding complications with antiplatelet agents: meta-analysis of 338,191 patients enrolled in 50 randomized controlled trials. Am J Hematol 2004;75:40-7.

24. Hankey GJ, Eikelboom JW. Aspirin resistance. BMJ 2004;328:477-9.

25. Gum PA, Kottke-Marchant K, Poggio ED, Gurm H, Welsh PA, et al. Profile and prevalence of aspirin resistance in patients with cardiovascular disease. Am J Cardiol 2001;88:230-5.

26. Patrono C. Aspirin resistance: definition, mechanisms and clinical read-outs. J Thromb Haemost 2003;1:1710-13.

27. Gibaldi M, Grundhofer B. Bioavailability of aspirin from commercial suppositories. J Pharm Sci 1975;64:1064-6.

28. Sagar KA, Smyth MR. A comparative bioavailability study of different aspirin formulations using on-line multidimensional chromatography. J Pharm Biomed Anal 1999;21:383-92.

29. Abdel-Rahman MS, Reddi AS, Curro FA, Turkall RM, Kadry AM, et al. Bioavailability of aspirin and salicylamide following oral coadministration in human volunteers. Can J Physiol Pharmacol 1991;69:1436-42.

30. Pulcinelli FM, Pignatelli P, Celestini A, Riondino S, Gazzaniga PP, et al. Inhibition of platelet aggregation by aspirin progressively decreases in long term treated patients. J Am Coll Cardiol 2004;43:979-84.

31. Gum PA, Kottke-Marchant K, Poggio ED, Gurm H, Welsh PA, et al. Profile and prevalence of aspirin resistance in patients with cardiovascular disease. Am J Cardiol 2001;88:230-5.

32. Tran HV, Waring ME, McManus DD, Erskine N, Do VTH, et al. Underuse of Effective Cardiac Medications Among Women, MiddleAged Adults, and Racial/Ethnic Minorities With Coronary Artery Disease (from the National Health and Nutrition Examination Survey 2005 to 2014). Am J Cardiol 2017;120:1223-9.

33. Singh Ranger G, McKinley-Brown C. Aspirin utilization, compliance and prevention of colorectal cancer - A single centre perspective. Available from: https://academic.oup.com/annonc/article/27/suppl 6/1342P/2800238. [Last accessed on 19 Nov 2018] 